\title{
Implikasi Penetapan Usia Minimal Nikah Menurut Pasal 7 Undang-Undang No. 1 Tahun 1974 di Kabupaten Majene
}

\author{
Hamsyim $^{1}$ \\ Kementerian Agama Kabupaten Majene Jl. Abd. Rahim Majene, Prov. Sulbar. \\ Email: ${ }^{1}$ hasyimharun@gmail.com
}

\begin{abstract}
This research was a field research. This study emphasized the implications in determining the age of marriage in Article 7 of Act No. 1 of 1974 concerning marriage. This study examined the causes of minimum marriage age and the impact. The nature of this research was qualitative, which examined the sources obtained in field studies. This study was focused to examine the minimum age of marriage in Majene Regency. The analysis used in this study is descriptive qualitative. The results of this study indicated that the cause of marriage age in Majene Regency is the role of parents, low educational level, culture, economy and environment. The implications of determining the minimum age for marriage have a negative impact on the biological and psychological aspects and have a broader chance for children to drop out of school.
\end{abstract}

Keywords: Implication-Minimum Marriage Age-Mejene District.

\begin{abstract}
Abstrak
Penelitian ini merupakan penelitian lapangan. Kajian ini menekankan pada implikasi dalam penetapan usia nikah dalam Pasal 7 UU No. 1 Tahun 1974 tentang perkawinan. Kajian ini menelaah penyebab terjadinya perkawinan usia minimal nikah dan dampak yang ditimbulkan dengan usia minimal menikah. Sifat penelitian ini merupakan kualitatif, yang menelaah sumber yang diperoleh dalam studi lapangan. Fokus dalam kajian ini dengan menelaah pernikahan usia minimal menikah di Kab. Majene. Analisis yang digunakan dalam penelitian ini dengan menggunakan deskriptif kualitatif. Hasil penelitian ini menunjukkan bahwa penyebab nikah usia nikah di Kab. Majene adalah peran orang tua, rendahnya pendidikan, budaya, ekonomi, pergaulan dan pendidikan. Implikasi dalam penetapan usia minimal menikah menimbulkan dampak buruk dalam aspek biologis, psikologis dan menyebabkan anak putus sekolah.
\end{abstract}

KataKunci: Implikasi-Usia Minimal-Nikah-Kab.Mejene. 
Hasyim:

"Implikasi Penetapan Usia Minimal Nikah Menurut Pasal 7 Undang-Undang No. 1 Tahun 1974 di Kabupaten Majene"

\section{Pendahuluan}

Perkawinan adalah ikatan lahir batin antara seorang laki-laki dan perempuan untuk memenuhi tujuan hidup berumah tangga sebagai suami istri dengan memenuhi syarat dan rukun yang telah ditentukan oleh syariat Islam. ${ }^{1}$ Keluarga menjadi institusi yang sangat penting dalam kehidupan bermasyarakat sebagai sarana awal untuk mewujudkan sebuah tatanan masyarakat dan keluarga sebagai pilar penyokong kehidupan bermasyarakat yang aman, damai dan tenteram. $^{2}$

Dalam Alquran al-Rum/30:21 mengisyaratkan bahwa salah satu bukti kebesaran Allah swt adalah dengan menciptakan istri-istri supaya cenderung merasa tenteram (لتسكنو اليها). ${ }^{3}$ Tujuan dari disyariatkan perkawinan adalah untuk mendapatkan keturunan. Islam menganjurkan kepada umatnya untuk memilih pasangan suami istri yang baik (berdasarkan agamanya) sehingga dapat melahirkan keturunan (generasi pengganti) sebagaimana yang diharapkan. ${ }^{4}$

Hukum pernikahan di Indonesia nampak dirasakan pentingnya pembatasan umur untuk mencegah praktek pernikahan terlampau muda yang sering menimbulkan berbagai akibat negatif. Pasal 7 ayat (1) UU No. 1 tahun 1974 tentang perkawinan menetapkan bahwa batas usia minimal bagi pria 19 (sembilan belas) tahun dan pihak wanita mencapai umur 16 (enam belas) tahun. Sejalan dengan KHI Pasal 15 ayat (1) bahwa untuk kemaslahatan keluarga dan rumah tangga, pernikahan hanya boleh dilakukan calon mempelai yang telah mencapai umur yang ditetapkan dalam Pasal 7 UU No. 1 tahun $1974 .^{5}$

Usia nikah merupakan salah satu faktor penting dalam keberlangsungan pernikahan. Usia pasangan pengantin masih relatif muda dapat berujun pada perceraian. Usia seseorang menjadi salah satu ukuran seseorang sudah cukup dewasa dalam bersikap. Meskipun tidak semuanya di usia muda tidak mampu

${ }^{1}$ M. Afnan Hafidh dan A. Ma'ruf Asrori, Tradisi Islami: Panduan Prosesi Kelahiran, Pernikahan dan Kematian (Surabaya: Khalista, 2009), h. 88. h. 285.

${ }^{2}$ Abdul Jalil, Fiqh Rakyat: Pertautan Fiqh dengan Kekuasaan (Yogyakarta: LKIS, 2000),

${ }^{3}$ Lihat QS al-Rum/30:21 dalam Kementerian Agama, Alquran dan Terjemahnya, h. 644.

${ }^{4}$ Jamaluddin, Buku Ajar Hukum Perkawinan (Lhoksumawe: Unimal Press, 2016), h. 45.

6.

${ }^{5}$ Hilman Hadikusuma, Hukum Perkawinan Indonesia (Bandung: Mandar Maju, 1990), h. 
Hasyim:

"Implikasi Penetapan Usia Minimal Nikah Menurut Pasal 7 Undang-Undang No. 1 Tahun 1974 di Kabupaten Majene"

berpikir dewasa. Namun faktor usia menjadi salah satu faktor tingginya angka perceraian.

Usia nikah muda marak terjadi diberbagai daerah, di Kabupaten Majene Provinsi Sulawesi Barat, telah mengalami peningkatan angka pernikahan di usia minimal nikah. Berdasarkan data awal pernikahan di usia minimal nikah yang tercatat dari Kantor Urusan Agama (KUA) Kec. Banggae Timur Kabupaten Majene bahwa pernikahan batas usia nikah banyak terjadi. ${ }^{6}$ Hal itu bukan sesuatu yang dilarang dalam Undang-Undang dan agama, tetapi keadaan umur nikah muda rentang muncul berbagai persoalan rumah tangga. Pemerintah telah aktif dalam mensosialisasikan dampak pernikahan di usia minimal nikah.

Pemberian izin nikah di Kab. Majene tidak mempertimbangkan kebahagiaan rumah tangga sebagai tujuan perkawinan. Pertimbangan yang sering dijadikan dasar bahwa kedua calon pengantin sudah terlalu akrab dan susah untuk dipisahkan dan faktor kehamilan. Pemberian izin telah melemahkan batas usia nikah dalam Pasal 7, sehingga implementasi batas usia nikah dengan penerapan Pasal 7 UU No. 1 tahun 1974 perlu diteliti. Hal itu dilakukan untuk membuktikan penerapan batas usia minimal nikah yang ditetapkan dalam Pasal 7 UU No. 1 Tahun 1974 dalam perkawinan di Kab. Majene serta implikasi materi Pasal 7 dalam mempertimbangkan kemaslahatan dan kelangsungan perkawinan.

\section{Metodologi}

Penelitian ini adalah penelitian kualitatif dengan metode diskriptif. Penelitian ini dilakukan di Kab. Majene Provinsi Sulawesi Barat. Lokasi ini dipilih karena pertimbangan bahwa jumlah perkawinan di usia dini dan di batas usia minimal telah mengalami perkembangan. Perkawinan di usia tersebut juga telah menjadi penyumbang angka perceraian di Kab. Majene. Sehingga data hasil observasi di Pengadilan Agama Kab. Majene menunjukkan bahwa bertambahnya angka cerai termasuk cerai gugat berasal dari pernikahan dini dan di usia minimal nikah. Pendekatan dalam penelitian ini di ataranya; pendekatan normatif, yuridis 
Hasyim:

“Implikasi Penetapan Usia Minimal Nikah Menurut Pasal 7 Undang-Undang No. 1 Tahun 1974 di Kabupaten Majene"

dan sosiologis. Penelitian ini menggunakan triangulasi dalam pengujian keabsahan data.

\section{Pembahasan}

\section{Penyebab Terjadinya Pernikahan di Usia Minimal di Kab. Majene}

Provinsi Sulawesi Barat menempati peringkat nomor satu sebagai daerah dengan angka perkawinan anak tertinggi di Indonesia. Menurut data BPS (Badan Pusat Statistik) tahun 2016 menyebutkan di Sulawesi Barat nilai rata-rata pertumbuhan perkawinan anak sebesar 37 persen. Hal itu diperkuat dengan pendataan keluarga terkait usia kawin di Sulawesi Barat tahun 2017, bahwa untuk perempuan yang menikah di bawah usia 21 tahun mencapai 114.741 orang dan laki-laki yang menikah di bawah usia 25 tahun mencapai 94.567 orang. ${ }^{7}$

Penyebab terjadinya pernikahan di usia muda disebabkan beberapa faktor, yakni faktor eksteren dan interen. Faktor eksteren di antaranya:

(a) Orang tua/keluarga

Orang tua atau keluarga memiliki banyak andil dalam terjadinya pernikahan di usia minimal. Rendahnya pengetahuan orang tua menjadi salah satu penyebab pernikahan tersebut. Mereka tidak memiliki wawasan atau pengetahuan yang cukup tentang hakikat perkawinan yaitu terbentuknya keluarga yang harmonis, sejahtera dan bahagia. Riadiah mengemukakan bahwa:

Orang tua sebenarnya dapat menunda perkawinan anaknya yang masih di usia minimal nikah, tetapi lamaran terhadap anaknya tetap diterima. Mereka tidak memikirkan bagaimana anak-anak mereka menjalani kehidupan setelah menikah. Mereka hanya berpikir bagaimana anak mereka menikah dan sekaligus tanggungjawab sebagai orang tua sudah selesai. Anak pun menjalani pernikahan itu dalam kondisi keterpaksaan dan semata pengabdian kepada orang tua bukan dengan kesiapan yang matang. ${ }^{8}$

Kondisi inilah yang terjadi di sebahagian masyarakat Kab. Majene, mereka tidak memikirkan apa yang sesungguhnya akan terjadi setelah anaknya menikah. Jika ada yang melamar anaknya, maka mereka pun menerimanya. Hal ini lebih

${ }^{7}$ https:lifestyle.okezone.com/read/2018/04/12.

${ }^{8}$ Riadiah Riadiah Zakariyah (52 tahun), Kepala Dinas Pemberdayaan Perempuan Dan Perlindungan Anak Kabupaten Majene, Wawancara, Majene, 24 Oktober 2018. 
Hasyim:

"Implikasi Penetapan Usia Minimal Nikah Menurut Pasal 7 Undang-Undang No. 1 Tahun 1974 di Kabupaten Majene"

banyak terjadi di daerah pesisir seperti di Kelurahan Baurung Kecamatan Banggae Timur Kab. Majene.

(b) Budaya/ada istiadat

Pengaruh budaya atau adat istiadat memberi kontribusi pernikahan di usia minimal nikah. Hal ini disebabkan oleh adanya pemahaman yang keliru dari sebahagian masyarakat di Kab. Majene. Muhammad Jufri mengemukakan bahwa:

Mereka merasa mendapat kehormatan dan kebanggaan ketika anak mereka cepat mendapatkan jodoh dan menikah. Sekaligus merasa khawatir jika anaknya tidak ada yang melamar jika sang orang tua menolak lamaran sebelumnya. ${ }^{9}$

Penjelasan Muhammad Jufri tersebut, bagi sebahagian orang tua di lingkungan Tamo dan sekitarnya sudah menjadi budaya atau adat. Meskipun masih ada masyarakat yang tidak sepakat menikahkan anaknya di usia dini. Golong yang tidak sepaham dengan itu adalah kalangan masyarakat berpendidikan. Kentalnya paradigma masyarakat akan pernikahan menjadi salah satu penyebab pernikahan usia dini di Kab. Majene. Paradigma itu selalu dihubungkan dengan kondisi zaman dahulu, padahal orang tua harus memahami bahwa kondisi dahulu dengan sekarang sangatlah berbeda.

(c) Pergaulan

Sebahagian masyarakat Kab. Majene memahami secara ekstrim bahwa jika anak mereka sudah menjalin hubungan dengan lawan jenis (berpacaran), maka telah terjadi pelanggaran agama. Anak sudah sering berduaan dan telah diketahui oleh banyak masyarakat, maka orang tua wajib melindungi dan mencegahnya. Ketakutan terhadap azab Allah swt., sehingga mereka segera mengawinkan anaknya walaupun anak tersebut masih keberatan untuk dikawinkan.

Ada beberapa kasus yang terjadi yaitu seorang anak perempuan lari dari rumahnya, kemudian tinggal di rumah bapak imam. Dihadapan imam, anak tersebut berkisah bahwa telah berpacaran dengan seseorang dan meminta kepada imam untuk segera dikawinkan dengan pacarnya. Tanpa upaya lain, imam

${ }^{9}$ Muhammad Jufri (57), Kepala Lingkungan Tamo Kelurahan Baurung Kecamatan Banggae Timur Kabupaten Majene, Wawancara, Majene, 31 Agustus 2018. 
Hasyim:

"Implikasi Penetapan Usia Minimal Nikah Menurut Pasal 7 Undang-Undang No. 1 Tahun 1974 di Kabupaten Majene"

tersebut menghubungi keluarga kedua belah pihak untuk mengawinkan mereka, akhirnya perkawinan terjadi. ${ }^{10}$

(d) Ekonomi

Terbatasnya ekonomi keluarga juga memberi andil besar dalam terjadinya pernikahan di usia minimal. Semakin berat biaya hidup dalam rumah tangga tentu akan memberi pengaruh pentin dalam pengambilan putusan terhadap berbagai persoalan rumah tangga. Sementara pada sisi lain, rumah tangga juga diharapkan agar tetap eksis dalam masyarakat. Muhammad Jufri mengemukakan:

Ketika ada seorang pemuda yang melamar seorang wanita, maka orang tua dari wanita tersebut segera menerima lamaran pria dengan alasan mengurangi beban biaya hidup keluarga. ${ }^{11}$

Mengawinkan anak dengan alasan ekonomi menjadi jalan alternatif untuk menyelesaikan persoalan kekurangan kebutuhan rumah tangga. Data dari Kementerian Agama Kab. Majene pada Seksi Bimbingan Masyarakat Islam menunjukkan data tiga tahun terakhir yaitu 2016, 2017, 2018, terdiri dari 8130 orang menikah. Sekitar 3858 orang menikah dengan pekerjaan tidak menentu. ${ }^{12}$ Kondisi ini tentu sangat memprihatinkan bagi si anak tersebut karena di samping masih berumur usia muda, mereka juga tidak memiliki keahlian bekerja yang mamadai sehingga mereka rata-rata belum memiliki mata pencaharian yang tetap.

Faktor interen penyebab terjadinya pernikahan usia minimal nikah di Kab. Majene di antaranya:

(a) Pendidikan

Pendidikan merupakan persoalan tersendiri yang memberi pengaruh terjadinya pernikahan. Rendahnya pendidikan seorang anak memiliki peran besar bagi perjalanan kehidupannya, termasuk dalam hal pernikahan. Sebahagian anak putus sekolah pada usia wajib sekolah yaitu mulai usia 9 (sembilan) sampai 18 (delapan belas) tahun telah melakukan perkawinan.

\footnotetext{
${ }^{10}$ Hasil Observasi di Lingkungan Tamo Kelurahan Baurung Kecamatan Banggae Timur Kabupaten Majene, Wawancara, Majene, 31 Agustus 2018.

${ }^{11}$ Muhammad Jufri (57), Kepala Lingkungan Tamo Kelurahan Baurung Kecamatan Banggae Timur Kabupaten Majene, Wawancara, Majene, 31 Agustus 2018.

${ }^{12}$ Data Rekapitulasi Peristiwa Nikah Menurut Pekerjaan pada Kementerian Agama Kabupaten Majene Tahun 2018.
} 
Hasyim:

"Implikasi Penetapan Usia Minimal Nikah Menurut Pasal 7 Undang-Undang No. 1 Tahun 1974 di Kabupaten Majene"

Penyebab rendahnya pendidikan anak yaitu: (1) faktor pribadi anak yang malas untuk belajar; (2) faktor minimnya perhatian orang tua terhadap pendidikan anak. Data yang ditemukan tiga tahun terakhir, sekitar 217 orang yang menikah tidak tamat Sekolah Dasar, 1.900 orang berpendidikan SD/Sederajat, 797 orang berpendidikan SMP/Sederajat dan 2.396 orang berpendidikan SMA/Sederajat. Jumlah keseluruhan orang menikah dengan jenjang pendidikan 0 sampai SMA/Sederajat adalah 5.200 orang. Jumlah ini sangat fantastis jika dilihat dari jumlah keseluruhan orang menikah pada tiga tahun terakhir yaitu 11.808 orang. ${ }^{13}$

Hal sama jika anak putus sekolah tersebut menganggur. Kekosongan waktu tanpa pekerjaan, akhirnya menjadikan mereka melakukan hal-hal yang tidak produktif. Menjalin hubungan dengan lawan jenis, berlanjut pernikahan, sehingga siap atau tidak, harus menjalani kehidupan rumah tangga. Jumlah perkawinan tiga tahun terakhir dengan umur antara 9 (sembilan) sampai 18 (delapan belas) tahun berjumlah 603 orang. ${ }^{14}$

Melangsungkan pernikahan seharusnya mempertimbangkan 2 kesiapan yaitu kesiapan fisik dan non fisik. Yang dimaksud dengan kesiapan fisik adalah materi dan seluruh rangkaiannya. Sedangkan non fisik adalah kemampuan seseorang dalam mengelolah problematika kehidupan rumah tangga atau sikap kedewasaan dalam berpikir untuk mencapai tujuan pernikahan.

(b) Kenakalan Remaja

Masa remaja sering dikenal dengan istilah masa pemberontakan. Pada masa ini, seorang anak seringkali menampilkan beragam gejolak emosi, menarik diri dari keluarga, serta mengalami banyak masalah, baik di rumah ataupun di lingkungannya.

Gagalnya remaja melewati masa transisi dari anak kecil menjadi dewasa, dan juga karena lemahnya pertahanan diri terhadap pengaruh dunia luar. Hal yang terjadi selanjutnya adalah konflik keluarga, depresi, dan munculnya berbagai tindakan berisiko terjadi. Koflik-konflik seperti inilah sangat sering terjadi pada masa remaja dibandingkan pada masa lain di sepanjang rentang kehidupannya.

\footnotetext{
${ }^{13}$ Data Kementerian Agama Kabupaten Majene cq. Bimas Islam pada Tanggal: 30 Juni 2018.

${ }^{14}$ Data Kementerian Agama Seksi Bimas Islam Kabupaten Majene.
} 
Hasyim:

"Implikasi Penetapan Usia Minimal Nikah Menurut Pasal 7 Undang-Undang No. 1 Tahun 1974 di Kabupaten Majene"

Akibatnya, para orang tua mengeluhkan perilaku anak-anaknya yang tidak dapat diatur, bahkan terkadang bertindak melawan mereka.

Kenakalan remaja merupakan tindakan melanggar peraturan atau hukum yang dilakukan oleh anak di bawah usia 18 (delapan belas) tahun. Perilaku yang ditampilkan dapat bermacam-macam, mulai dari kenakalan ringan seperti membolos sekolah, melanggar peraturan-peraturan sekolah, melanggar ketentuan orang tua, hingga kenakalan berat seperti vandalisme, perkelahian antara geng, penggunaan obat-obat terlarang, dan sebagainya. Hal-hal itu terjadi juga di Kab. Majene sebagai suatu realtas sosial di masyarakat.

Faktor lingkungan atau teman sebaya yang kurang baik juga ikut memicu timbulnya perilaku yang tidak baik pada diri remaja. Sekolah yang kurang menerapkan aturan yang ketat juga membuat remaja menjadi semakin rentan terkena efek pergaulan yang tidak baik. Guru yang kurang sensitif terhadap hal ini juga bisa membuat remaja menjadi semakin sulit diperbaiki perilakunya.

Demikian juga dengan guru yang terlalu keras dalam menghadapi remaja yang bermasalah. Bisa jadi, bukannya ikut meredam kenakalan mereka, malah membuat kenakalan mereka semakin menjadi. Begitu juga dengan anak remaja, jika orangtua terlalu mengekang anak, yang terjadi adalah anak tidak mampu berkembang secara mandiri dan mereka akan berusaha untuk melepaskan dirinya dari kekangan orangtua. Ketika hal ini terjadi, lingkungan sosial, terutama teman sebaya, akan menjadi pelarian utama si anak.

Lingkungan sosial tempat anak biasa berkumpul memiliki kecenderungan untuk melakukan kenakalan remaja, maka anak juga berpotensi besar untuk melakukan hal yang sama dengan apa yang dilakukan kelompoknya. Hal yang sama juga dapat terjadi apabila orangtua terlalu membebaskan anak. Perbedaannya adalah, anak yang dibebaskan tidak merasakan tekanan sebesar apa yang dirasakan oleh anak yang ditekang, sehingga dorongan untuk memberontak cenderung lebih kecil dibandingkan anak yang dikekang. Orang tua tetap bisa mengawasi aktivitas dan pergaulan anaknya dengan pasif. Masfar Ahmad mengemukakan: 
Hasyim:

"Implikasi Penetapan Usia Minimal Nikah Menurut Pasal 7 Undang-Undang No. 1 Tahun 1974 di Kabupaten Majene"

Tidak ada kata terlambat dalam menangani anak remaja yang terlihat 'melenceng'. Karena di usia ini teman adalah segalanya bagi anak, ia dapat dengan mudah terpengaruh oleh teman-teman sebayanya. Termasuk dalam pembinaan rumah tangga anak.Orang tua memiliki peran yang sangat besar terhadap keberlangsungan pernikahan anaknya. Orang tua harus berada disisi mereka. Entah perkawinan dini atau dewasa, orang tua mestinya senantiasa memberikan petunjuk dan bimbingan, bahkan senantiasa mendampingi mereka untuk menyelesaikan persoalan-persoalan rumah tangganya. ${ }^{15}$

Perkembangan teknologi cukup dahsyat membawa dampak positif dan negatif. Salah satu dampak negatif yang ditimbulkan meningkatnya kenakalan remaja. Dunia saat ini di istilahkan dengan small town (atau kota kecil). Kecanggihan teknologi telah membuka tabir sekaligus menutup jarak yang panjang untuk menyaksikan berbagai tontonan perilaku yang baik dan tidak baik di seluruh pelosok dunia.

Hal serupa telah melanda sebahagian generasi masyarakat Kab. Majene, dalam hasil observasi menunjukkan anak-anak yang memiliki alat canggih menyaksikan berbagai bentuk pornografi dan pornoaksi yang dapat disaksikan kapan dan dimana saja. Di sisi lain orang tua yang membekali mereka alat tersebut tidak melakukan pengawasan yang ketat. Sehingga anak remaja yang tadinya hanya melihat melalui internet akhirnya berusaha mencoba-coba suatu sifat yang buruk kemudian berlanjut menjadi bentuk perilaku pada dirinya.

(c) Hamil sebelum menikah

Beberapa kasus di Kab. Majene yang diajukan ke Pengadilan Agama untuk mendapatkan dispensasi nikah karena kedua anak (pria dan wanita) telah melakukan hubungan biologis layaknya suami istri. Kondisi seperti itu, orang tua anak perempuan terpaksa untuk segerah menikahkan anaknya. Orang tua anak gadis ini memahami bahwa anaknya sudah tidak perawan lagi dan harus segera dinikahkan karena perbuatan itu menjadi aib dalam rumah tangga.

Solusi yang ditawarkan tentus ecara keseluruhan tidaklah menyelesaikan masalah karena kemungkinan di kemudian hari pernikahan itu akan menyesatkan

${ }^{15}$ Masfar Ahmad (65 tahun), Sekertaris MUI Kab. Majene sekaligus sebagai tokoh agama, Wawancara, Majene, 12 November 2018. 
Hasyim:

"Implikasi Penetapan Usia Minimal Nikah Menurut Pasal 7 Undang-Undang No. 1 Tahun 1974 di Kabupaten Majene"

anak-anak. Ibarat anak sudah melakukan suatu kesalahan besar, bukan memperbaiki kesalahan tersebut, tetapi orang tua justru membawa anak pada masalah baru. Karena kemungkinan besar di kemudian hari perkawinan mereka tersebut akan dipenuhi konflik.

Bahkan ada beberapa kasus, walau pada dasarnya orang tua anak gadis ini tidak setuju dengan calon menantunya, tapi karena kondisi kehamilan gadis, terpaksa orang tua menikahkan anak gadis tersebut. Kasus lain justru anak gadis tersebut pada dasarnya tidak mencintai calon suaminya, tapi karena terlanjur hamil, maka dengan sangat terpaksa mengajukan permohonan dispensasi kawin. Ini semua tentu menjadi hal yang sangat dilematis, baik bagi anak gadis, orang tua bahkan hakim yang menyidangkan. Karena dengan kondisi seperti ini, jelasjelas perkawinan yang akan dilaksanakan bukan lagi perkawinan sebagaimana yang diamanatkan dalam Islam.

Hasil wawancara ketua Pengadilan Agama Majene bahwa:

Ada beberapa permintaan dispensasi nikah di Kab. Majene dengan alasan bahwa calon pengantin perempuan telah hamil diluar nikah. Kondisi ini sangat sulit bagi Pengadilan Agama untuk menolak permohonan dispensasi tersebut sehingga harus dikabulkan. ${ }^{16}$

Walaupun ada juga kasus yang terjadi mereka langsung bercerai ketika anak mereka telah lahir. Kondisi seperti inilah yang sangat mengkhawatirkan karena orang tua dari anak yang baru saja dilahirkan tidak melaksanakan tanggung jawabnya dengan baik. Bisa dibayangkan bahwa anak-anak mereka akan tumbuh menjadi dewasa tanpa orang tua memberikan bimbingan dan perlindungan.

Kasus yang dialami oleh Busman Hasan Bin Hasan yang telah mengajukan dispensasi nikah kepada Pengadilan Agama Kab. Majene untuk mendapatkan izin menikahkan anaknya yang bernama Riswan yang baru berumur 18 tahun. Melalui putusan pengadilan dengan Nomor Perkara; 270/Pdt.P/2018/PA.Mj tertanggal 24 Oktober 2018 akhirnya Pengadilan Agama Kab. Majene memutuskan menerima

${ }^{16}$ Dewiati (47 tahun), Ketua Pengadilan Agama Kabupaten Majene, Wawancara, Majene, 29 Agustus 2018. 
Hasyim:

“Implikasi Penetapan Usia Minimal Nikah Menurut Pasal 7 Undang-Undang No. 1 Tahun 1974 di Kabupaten Majene"

permohonan Busman untuk menikahkan Riswan dengan seorang perempuan bernama Sarni dengan alasan telah hamil diluar nikah. ${ }^{17}$

Busman mengisahkan keadaan Riswan anaknya, sehingga terpaksa menikahkan dengan Sarni bahwa:

Ketika 5 bulan anaknya Riswan masuk di SMK5 Kabupaten Majene sebagai siswa baru langsung berkenalan dengan Sarni. Sarni waktu itu satu kelas dengan Riswan. Sejak itu mereka berpacaran dan sudah lebih 1 1/2 tahun berlangsung. Mereka sering bertemu di rumah Busman atau di rumah orang tua Sarni. Sebenarnya sudah berusaha maksimal memutus hubungan percintaan mereka namun karena selaku orang tua sibuk melaut dan apalagi ada alat komunikasi (hp) yang mereka gunakan sehingga intensitas pertemuan mereka sangat lancar. Bahkan tetangga kami tidak percaya jika anak saya melakukan perbuatan yang dilarang agama tersebut karena Riswan termasuk anak pendiam di sekitar rumahnya. Tetapi tidak ada lagi jalan keluar kecuali harus dinikahkan. ${ }^{18}$

Hasil wawancara peneliti dengan Busman bahwa merasa gagal mendidik anaknya dan menyesali perbuatan tersebut. Ia merasa telah mendapat pelajaran yang sangat berharga dalam mendidik anak. Hal seperti inilah yang sangat perlu diketahui masyarakat bahwa orang tua memiliki peran yang sangat kuat dalam mendidik dan mengawasi pergaulan anaknya. Tidak ada arti penyesalan ketika kejadian tersebut sudah terjadi.

\section{Dampak Negatif Pernikahan di Usia Minimal di Kab. Majene}

(a) Dampak Biologis

Pernikahan anak di dini dan di usia minimal nikah sangat membahayakan bagi jiwa seseorang. Secara biologis alat-alat reproduksi mereka masih dalam proses menuju kematangan sehingga belum siap untuk melakukan hubungan seks dengan lawan jenisnya, apalagi jika sampai hamil kemudian melahirkan. Jika dipaksakan justru akan terjadi trauma, perobekan yang luas dan infeksi yang akan membahayakan terhadap organ reproduksinya. Patut dipertanyakan apakah hubungan seks yang demikian atas dasar kesetaraan dalam hak reproduksi antara

\footnotetext{
${ }^{17}$ Busman Hasan (51 tahun), selaku orang Riswan, Wawancara, Majene, 10 November 2018.

${ }^{18}$ Busman Hasan (51 tahun), selaku orang Riswan, Wawancara, Majene, 10 November 2018.
} 
Hasyim:

"Implikasi Penetapan Usia Minimal Nikah Menurut Pasal 7 Undang-Undang No. 1 Tahun 1974 di Kabupaten Majene"

istri dan suami atau adanya kekerasan seksual dan pemaksaan terhadap seorang anak.

(b) Dampak Psikologis

Pada hakikatnya pernikahan anak di usia minimal dianggap belum siap secara psikologis sehingga dapat menimbulkan trauma psikis berkepanjangan dalam jiwa anak yang sulit disembuhkanapalagi belum terlalu mengerti tentang hubungan seks. Remaja yang menikah sebelum menginjak usia 18 tahun, sekitar $41 \%$ lebih berisiko untuk mengalami gangguan mental seperti depresi dan kepribadian ganda. Namun, tidak cuma itu saja dampaknya. Ada beragam persoalan negatif lainnya akibat perkawinan anak, terutama pada kesehatan tubuh remaja perempuan.

Jiwa yang masih muda karena sudah berkeluarga, seorang anak perempuan dituntut untuk menjadi seorang ibu dari anak-anaknya. Memberi asupan susu kepada anaknya, merawat dan mendidik anaknya, serta mengatur belanja rumah tangga dan dapurnya. Dan pada sisi lain ia harus melayani suami. Semua ini bukanlah pekerjaan yang mudah dilaksanakan bagi yang masih berumur usia muda. Banyak terjadi percekcokan dalam rumah tangga. Di usia muda yang masih butuh bermain, bercengkrama dengan teman sejawatnya tetapi ia dituntut sebuah tanggung jawab yang besar untuk mengatur kehidupan keluarganya.

(c) Dampak Pendidikan

Anak-anak yang menikah di usia minimal masih dalam jenjang pendidikan. Terpaksa menikah di usia 16 tahun ke bawah, mereka pasti masih berada di bangku sekolah. Rata-rata anak yang terlanjur menikah tersebut tidak lanjut lagi bersekolah. Hal ini diakibatkan rasa malu yang mendalam untuk bergaul dengan teman sekolahnya karena sudah punya suami dan anak. Di samping itu juga, harus mengatur waktu untuk lebih banyak di rumah untuk memberi perhatian dan layanan dalam melaksanakan tanggung jawabnya sebagai bapak atau ibu.

Anak putus sekolah tersebut maka tentu mereka tidak dapat mengenyam pendidikan lebih tinggi. Padahal kualitas anak dalam rumah tangga sangat 
Hasyim:

"Implikasi Penetapan Usia Minimal Nikah Menurut Pasal 7 Undang-Undang No. 1 Tahun 1974 di Kabupaten Majene"

dipengaruhi tingkat pendidikan bapak dan ibunya. Apabila mereka tidak memiliki pendidikan yang cukup, maka bisa dibayangkan bahwa di keluarga itu tidak akan mampu mengembangkan pendidikan anaknya sekaligus tidak mampu mengangkat derajat keluarganya dari pra sejahtera menjadi sejahtera. Mereka akan menjalani kehidupan rumah tangga sekedar apa adanya tanpa ada motivasi atau dorongan yang kuat untuk mensejahterahkan keluarganya.

(d) Dampak Ekonomi

Pasangan suami-istri yang menikah di usia minimal sangat mempengaruhi ekonomi keluarga. Rata-rata mereka yang menikah di usia tersebut belum mapan dalam pekerjaan. Mungkin sebahagian sudah mendapatkan pekerjaan tetapi belum berlangsung secara kontinyu ${ }^{19}$ sehingga rumah tangga tersebut akan mengalami kesulitan ekonomi. Sementara pada sisi lain kebutuhan biaya rumah tangga setiap tahun meningkat. Suami istri yang tidak memiliki kemampuan dalam mengatur keuangan rumah tangga tentu akan kesulitan dalam memenuhi kebutuhan mereka sendiri.

Data kasus perceraian yang terdapat pada Kantor Pengadilan Agama Kab. Majene menunjukkan bahwa persoalan ekonomi menjadi salah satu penyebab penting terjadinya perceraian ${ }^{20}$. Menurut Dewiati, SH., MH. selaku Ketua Pengadilan Agama Kab. Majene bahwa "persoalan ekonomi menjadi salah satu faktor utama penyebab perceraian rumah tangga terjadi. Walaupun masih ada penyebab lain yaitu antara lain ketidak cocokan dan adanya pihak ketiga."21

(e) Dampak Sosial

Keluarga merupakan bahagian penting dalam kehidupan social bermasyarakat. Tidak adanya keluarga dalam masyarakat, maka dapat dikatakan tidak ada kehidupan bersosial. Demikian juga bahwa sukses dan stabilnya kehidupan bersosial di masyarakat, sangat dipengaruhi oleh kesuksesan pembinaan dari keluarga-keluarga terkecil dalam rumah tangga.

${ }^{19}$ Data Pernikahan berdasarkan Pekerjaan Kantor Kementerian Agama Kab.Majene Tanggal 2 Juli 2018. 2018 .

${ }^{20}$ Data Perceraian pada Kantor Pengadilan Agama Kab.Majene pertanggal 4 September

${ }^{21}$ Dewiati (47 tahun), Ketua Pengadilan Agama Kabupaten Majene, Wawancara, Majene, 29 Agustus 2018. 
Hasyim:

“Implikasi Penetapan Usia Minimal Nikah Menurut Pasal 7 Undang-Undang No. 1 Tahun 1974 di Kabupaten Majene"

Banyaknya perceraian dalam masyarakat sebagai akibat dari bertambahnya pernikahan dini atau nikah di usia minimal nikah, tentu akan memberi kontribusi negatif dalam masyarakat yaitu anak yang ditinggalkan akan menjadi beban masyarakat. Anak-anak tersebut dapat menjadi liar melakukan kejahatan, pencurian, berbuat onar dan lain-lain sehingga mengganggu ketentraman masyarakat. Suami istri yang bercerai juga dapat melakukan pelecehan/merusak rumah tangga orang lain. ${ }^{22}$

Oleh karenanya, diharapkan adanya pembinaan yang maksimal dari keluarga terhadap seluruh anggotanya masing-masing. Setiap keluarga berupaya memberikan kedamaian dalam rumah tangganya sehingga dalam satu komunitas atau lingkungan akan tercipta ketenangan dan kedamian.

Peneliti telah menemukan satu kasus yaitu ketika suami istri sudah tidak mampu lagi menafkahi keluarganya dan sekaligus telah memiliki banyak hutang, akhirnya suaminya meminta untuk berpisah dengan istrinya. Padahal mereka memiliki anak yang berusia masih balita. Orang tua, saudara kandung dan ipar memberikan bantuan hanya sekedarnya saja, dan itu dalam bentuk hutang bukan sedekah atau sumbangan. Pada hal suami istri tersebut sangat membutuhkan bantuan. Orang tua maupun saudara juga tidak patut untuk dipersalahkan secara penuh karena keadaan merekapun dalam kondisi pas-pasan. ${ }^{23}$

Hal inilah yang ditemukan peneliti dalam masyarakat di Kab. Majene bahwa kondisi dahulu dengan sekarang telah mengalami perubahan yang besar yaitu adanya pergeseran pemahaman dalam pembinaan keluarga. Hal tersebut diakibatkan oleh 2 hal yaitu: Pertama, kebutuhan biaya hidup semakin mahal dan Kedua, adanya perubahan pola pikir akibat globalisasi melalui perkembangan teknologi dan informasi.

\footnotetext{
${ }^{22}$ Hasil Observasi data-data penyebab perceraian di Pengadilan Agama Kab. Majene, 29 Agustus 2018.

${ }^{23}$ Atas permintaan istri, mereka ingin dipertemukan di Kantor Urusan Agama Kec. Banggae Timur Kab. Majene. Saat itu penulis masih menjabat sebagai Kepala KUA. Si istri meminta bantuan ke KUA agar suaminya diberi nasehat sekaligus dicegah untuk menceraikannya. Hasil pertemuan, rupanya sang suami tetap kokoh pada pendirian awal untuk tetap menceraikan istrinya, bahkan suaminya mengancam meninggalkan istri dan anaknya berangkat ke Malaysia dengan alasan bahwa hutang piutang mereka sudah terlalu banyak dan tidak dapat ditebus lagi. Kasus ini terjadi pada bulan Oktober 2017.
} 


\section{Punutup}

Berangkat dari pembahasan sebelumnya, maka dapat diuraikan beberapa simpulan dalam penelitian ini di antaranya; (1) pengaruh terjadinya pekawinan di usia dini pada masyarakat Kab. Majene disebabkan oleh dua faktor. Pertama, faktor eksternal meliputi tekanan orang tua, budaya atau adat, pemahaman agama yang masih dangkal dan pengaruh ekonomi. Kedua, rendahnya tingkat pendidikan, kenakalan remaja dan buntut kenakalan yang mengakibatkan kehamilan. (2) Dampak yang ditimbulkan dengan pernikahan dini di Kab. Majene di antaranya aspek biologis yang dapat mengakibatkan kematian. Dampak lain yang ditimbulkan adalah tekanan psikologi yang dihadapi dalam perkawinan. 
Hasyim:

"Implikasi Penetapan Usia Minimal Nikah Menurut Pasal 7 Undang-Undang No. 1 Tahun 1974 di Kabupaten Majene"

\section{Daftar Pustaka}

Alquran dan Terjemahnya

Data Rekapitulasi perkawinan Tahun 2018 KUA Kec. Banggae Timur Kab. Majene.

Data Rekapitulasi Peristiwa Nikah Menurut Pekerjaan pada Kementerian Agama Kabupaten Majene Tahun 2018.

Data Kementerian Agama kabupaten Majene cq. Bimas Islam pada Tanggal: 30 Juni 2018.

Kementerian Agama RI. Pedoman Konselor Keluarga Sakinah. Jakarta: t.p., 2001.

Hafidh, M. Afnan dan A. Ma'ruf Asrori. Tradisi Islami: Panduan Prosesi Kelahiran, Pernikahan dan Kematian. Surabaya: Khalista, 2009.

Hadikusuma, Hilman. Hukum Perkawinan Indonesia. Bandung: Mandar Maju, 1990.

Jalil, Abdul. Fiqh Rakyat: Pertautan Fiqh dengan Kekuasaan. Yogyakarta: LKIS, 2000.

Jamaluddin. Buku Ajar Hukum Perkawinan. Lhoksumawe: Unimal Press, 2016.

\section{Informan Penelitian}

Riadiah Riadiah Zakariyah (52 tahun), Kepala Dinas Pemberdayaan Perempuan Dan Perlindungan Anak Kabupaten Majene, Wawancara, Majene, 24 Oktober 2018.

Muhammad Jufri (57), Kepala Lingkungan Tamo Kelurahan Baurung Kecamatan Banggae Timur Kabupaten Majene, Wawancara, Majene, 31 Agustus 2018.

Masfar Ahmad (65 tahun), Sekertaris MUI Kab.Majene sekaligus sebagai tokoh agama, Wawancara, Majene, 12 November 2018.

Dewiati (47 tahun), Ketua Pengadilan Agama Kabupaten Majene, Wawancara, Majene, 29 Agustus 2018.

Busman Hasan (51 tahun), selaku orang Riswan, Wawancara, Majene, 10 November 2018.

Dewiati (47 tahun), Ketua Pengadilan Agama Kabupaten Majene, Wawancara, Majene, 29 Agustus 2018. 